\title{
Wherefore Art Thou? On the History, State and Prospects of Czech Epigraphy
}

Zarys treści: Autor omawia pokrótce stan badań nad czeską epigrafiką i wskazuje ich perspektywy na dalszą przyszłość.

Abstract: The author shortly describes the state of research on the Czech epigraphics; he shows the perspectives of these research for the future.

Słowa kluczowe: epigrafika, historiografia, zabytkowe nagrobki, metodologia, Republika Czeska. Keywords: epigraphy, historiography, sepulchral monuments, methodology, Czech Republic.

The Czech Republic does not stand in the forefront of European research in the field of Medieval and Modern epigraphy. Nevertheless it can present interesting and valuable results, particularly with regard to the limited possibilities of Czech epigraphic work. It may therefore be interesting to consider the opportunities for the disciplin's development.

The results of Czech epigraphic research have been summarised several times ${ }^{1}$; yet it is interesting for the international public to be reminded of its most important accomplishments. Nevertheless, the paper does not intend to be a commented full bibliography. The basis of supra-regional epigraphic research is making the materials accessible through editions and catalogues. Leaving aside unrealised projects from the period of the Austro-Hungarian Monarchy ${ }^{2}$, the first attempt at compiling a general list of inscriptions found on the territory of Bohemia comes from the period of World War II. In 1943 an epigraphic commission was established for this purpose by the Czech Academy of Science and Art. The immediate example was first volume of the series Die Deutschen Inschriften ${ }^{3}$, today the most comprehensive European

\footnotetext{
${ }^{1}$ For the last summary of Bohemian epigraphic research, see J. Roháček, in: Středověká a raně novověká epigrafika v České republice, Corpus Inscriptionum Slovaciae, vol. 1.1, Súpis nápisov zo Slovenska, vol. 1.1, Latinská epigrafia. Dejiny a metodika výskumu historickych nápisov zo Slovenska, Bratislava 2014, pp. 31-40. Among the earlier, see particularly I. Hlaváček, Die mittelalterliche Epigraphik in den böhmischen Ländern nach dem zweiten Weltkrieg, „Medievalia Bohemica”, 3, 1970, pp. 293-311, and a number of published reports, particularly by I. Hlaváček and J. Roháček. For the titles of these and other works, see Literaturbericht zur mittelalterlichen und neuzeitlichen Epigraphik (MGH, Hilfsmittel), which has been published from 1987 onwards (for literature from 1976).

2 Corpus antiquarum inscriptionum imperii austriaci, which initially aimed to include also a list of Moravian inscriptions. Cf. A. H. Zajic, Inschriften, in: Quellenkunde der Habsburgermonarchie (16.-18. Jahrhundert). Ein exemplarisches Handbuch, ed. J. Pauser, M. Scheutz, T. Winkelbauer, Wien-München 2004 (MIÖG, Ergänzungband 44), pp. 1095-1109, at p. 1104. See also V. Ř́hová, Corpus antiquarium inscriptionum imperii austriaci-proglomena k epigrafické sbírce z roku 1828, in: Epigraphica et Sepulcralia, vol. 7, ed. J. Roháček, Praha 2016 (in the press).

${ }_{3}^{3}$ Die Inschriften des badischen Main- und Taubergrundes. Wertheim-Tauberbischofsheim, ges. u. bearb. v. E. Cucuel u. H. Eckert, Vorw. zum Gesamtwerk v. F. Panzer, Stuttgart 1942, reprint 1969 (Die Deutschen Inschriften, vol. 1).
} 
edition of its kind, which had just been published. A special approach to the specificities of the Czech inscriptions was, however, emphasised. According to the uniform editorial schema, Medieval and Early Modern inscriptions, and a selection of Modern inscriptions up to the middle of the $19^{\text {th }}$ century from Bohemia, Moravia and Silesia were to be collected comprehensively. Master's marks and signatures (with the exception of bell founders), however, were not to be treated, and inscriptions on sphragistic and numismatic material were to be considered only as comparative materials. Activities did not truly begin until 1950, with the excerpting of the secondary literature, and ended in 1953 with the creation of the new Czechoslovak Academy of Sciences. The only lasting result was an unfinished card catalogue of the inscriptions mentioned in the secondary literature, which had been meant to be the background information for fieldwork ${ }^{4}$. The card catalogue, with more than 17,000 records, can be found at the Institute of Art History of the CAS, v.v.i ${ }^{5}$; it is currently being digitised.

Another attempt was the start of the publication, in 1996, of the Corpus inscriptionum Bohemiae ${ }^{6}$, again applying the (modified) methodology of Die Deutschen Inschriften ${ }^{7}$ to the Czech materials, with the terminus ante quem set, for a selection of more recent inscriptions, to the end of the $18^{\text {th }}$ century ${ }^{8}$. This selection concerns mainly important architectural, sepulchral, and bell inscriptions. Another shift of the terminus ante quem is then primarily limited by the explosive growth of sepulchral monuments in the newly established cemeteries extra muros as a consequence of the Josephine reforms of burial. The methodology of epigraphic work as it was predominantly developed to study Medieval materials is not an ideal instrument for grasping the inscriptions of the late $19^{\text {th }}$ and $20^{\text {th }}$ centuries, not to mention contemporary inscriptions.

Making Czech inscriptions accessible had a much longer tradition, starting from several medieval attempts and continuing in the Early Modern period. Works dealing with inscriptions start to have practical significance especially in the period of Baroque historiography in the second half of the $17^{\text {th }}$ and the $18^{\text {th }}$ centuries. Most important among the authors are Bohuslav Balbín ${ }^{9}$, Jaroslav Schaller ${ }^{10}$, and Jan Florian Hammerschmid ${ }^{11}$, whereas the genealogical-heraldic school is best represented by the scholarly estate of Gottfried Daniel Wunschwitz in the National Archive of the Czech Republic ${ }^{12}$. The work by Jan Pavel Cerroni crowned earlier inventories in Moravia ${ }^{13}$. A notable accent on inscriptions

\footnotetext{
${ }^{4}$ Masaryk Institute and Archive of the CAS, v.v.i., Czechoslovak Academy of Sciences and Art, Epigraphic Commission. The reports on the activities of the commission, see the relevant yearbooks of the Věstník České akademie věd a umění. On the card catalogue and on the commission, see J. Roháček, Kartotéka našich nápisü, „Umění”, 38, 1990, pp. $182-183$.

${ }^{5}$ IAH, CAS, v.v.i., Department of Documentation, Epigraphic Documentation, Card catalogue of the inscriptions of the CASA

6 J. Roháček, Nápisy města Kutné Hory, Praha 1996 (Corpus inscriptionum Bohemiae, 1, Fontes historiae artium III); P. Načeradská, Nápisy okresu Kutná Hora, Praha 2002 (Corpus inscriptionum Bohemiae, vol. 2, Fontes historiae artium, vol. 10).

${ }^{7}$ Die Deutschen Inschriften (since 1942, 90 territorially defined volumes have been published so far) and the methodological literature published subsequently. See also <www.inschriften.net $>$ [accessed on: 8.03.2016], where part of the volumes is accessible on-line.

8 The editions in Die Deutschen Inschriften treated the inscriptions according to the artificial cut-off date of 1650, or to a distinctive 'natural' milestone close to that cut-off date. Other large European corpora have the cut-off date set variously, depending on the specificities of the inscriptions' collection and successive research. Cf. e.g. Corpus inscriptionum Poloniae (1800), Corpus des inscriptions de la France médiévale (1300), Corpus inscriptionum medii aevi Helvetiae (1300), Corpus Inscriptionum Hispaniae Mediaevalium (1500), Epigrafia medieval Portuguesa / Corpus epigráfico medieval Portugues (1422), Inscriptiones Medii Aevi Italiae (1200).

${ }^{9}$ Especially Miscellanea historica regni Bohemiae, Praha 1679.

10 J. Schaller, Beschreibung der Königlichen Haupt und Residenzstadt Prag sammt allen darinn befindlichen sehenswürdigen Merkwürdigkeiten, t. 1-4, Praha 1794-1797, and other works.

11 J. F. Hammerschmid, Prodromus Gloriae Pragenae..., Praha 1734.

${ }_{12}$ National Archive, Genealogical-heraldic collection Wunschwitz. For basic information on the collection, including an inventory, see $<$ http://www.badatelna.eu/fond/186> [accessed on: 8.03.2016].

${ }_{13}$ Moravian Land Archive, G 12., on the collection Švábenský, Mojmír, Cerroni Collection: G 12: 13th century-1845, 3 vol., Brno 1973; cf. also <http://www.badatelna.eu/fond/20801/?q=cerroniho $>$ [accessed on: 8.03.2016].
} 
comes with the golden age of Czech regional research of the late $19^{\text {th }}$ and first third of the $20^{\text {th }}$ century. Its symbol was August Sedláček ${ }^{14}$, and its driving force was formed by a number of enthusiastic professionals and amateurs ${ }^{15}$. The later $20^{\text {th }}$ century also produced a number of works intersting from an epigraphic perspective. Especially the work of the classical philologists Bohuslav Ryba ${ }^{16}$ and Josef Hejnic $^{17}$ is worthy of note, not only from a material but also from a methodological perspective. In terms of their representativeness, the supra-regional monographs, devoted to individual groups of objects bearing inscriptions, and exhibition catalogues that include inscriptions, are very valuable. Besides these works, in Czech scholarship we find a large number of either primarily epigraphic works or works focused on the objects bearing the inscriptions which take into consideration also the quality of the inscriptions. They limit themselves mainly to the presentation of individual pieces or to small collections of inscriptions, and so are situated between the works of descriptive inventory and those of analysis in the strict sense of the word ${ }^{18}$.

The largest collection making accessible the Czech epigraphic heritage is the unfinished Soupis památek historických a uméleckých v království Českém [Inventory of the Historical and Artistic Monuments in the Kingdom of Bohemia $]^{19}$, covering about half of Bohemia (without Moravia), in which inscriptions have been given attention relatively systematically. It is more useful for epigraphic study than other European series of a similar character, for instance the otherwise exemplary Österreichische Kunsttopographie $e^{20}$, which provides only a small selection of the inscriptions' texts according to not always entirely clear criteria. The limits of epigraphic exploitation of the Soupis are, apart from its incompleteness, the fluctuating quality of the elaboration, which are dependent on the authors of the individual volumes. The rendering of the formal aspects of the inscriptions and the quality of the pictorial documentation are generally problematic. An exception is the reproduction of the frottage of the inscriptions on some monuments (in particular on bells and metal baptisteries) ${ }^{21}$. For a formal analysis, the Soupis is only minimally useful; it is much more useful for a rough assessment that can be deduced from the transcriptions of the inscribed texts regardless of their problematic quality.

\footnotetext{
${ }^{14}$ Sedláček scholarly estate (1843-1926) administered by the Institute of History of the CAS, Sedláče‘s card catalogue (more than 200,000 cards) on-line at <http://www.augustsedlacek.cz $>$ [accessed on: 8.03.2016].

${ }^{15}$ Besides the monographic works (cf. note 1), this generation contributed particularly intensively to periodicals and journals, starting with annual reports of various secondary schools and finishing with the journal „Archaeological Monuments” (started in 1854 as „Památky archaeologické a místopisné“; several name changes later on).

${ }^{16}$ B. Ryba, Nástěnné nápisy v kapli Betlémské, „Věstník Královské České společnosti nauk”, 6, 1952; idem, Epitafy v kapli Betlémské, „Věstník Královské České společnosti nauk”, 4, 1952.

${ }_{17}$ J. Hejnic, Náhrobky v lapidáriu Národního muzea, „Sborník Národního muzea v Praze”, 4, 1959; idem, O nápisných textech v lapidariu Národního muzea, „Časopis národního muzea”, 129, 1960, pp. 1-33; idem, Některé renesanční náhrobky v lapidariu Národního musea, „Časopis Národního muzea v Praze”, 128, 1959, pp. 46-63; idem, Nápisy na českých zvonech ve 14. až 16. století, „Časopis Národního musea, oddíl věd společenských”, 129 1960, pp. 1-33; idem, Dvě nápisné památky z doby husitské, „Sborník Národního muzea v Praze”, 15, 1961, nos. 4-5, pp. 235-256.

${ }^{18} \mathrm{Cf}$. the bibliographies in works mentioned in note 1 .

19 Soupis památek historických a uměleckých v království českém (v Čechách, v Republice Československé) od pravěku do počátku XIX. Století, 51 sv., 1897-1937. Other volumes have recently been published from the estate of the Archeaological Commission of the CASA in the Documentation Department of IAH of the CAS, v.v.i.: Edice nedokončeného soupisu uměleckých památek politického okresu pardubicko-holicko-přeloučského, napsal V. K. Vendl, ed. J. Marešová, Praha 2007 (Fontes historiae artium, vol. 13); Soupis památek historických a uměleckých v politickém okresu Ledečském. Edice nedokončeného rukopisu, napsali J. Soukup, J. Valchář, ed. J. Sommer, K. Uhlíková, Praha 2010 (Fontes historiae artium, vol. 14); K.F. Kühn, Verzeichnis der kunstgeschichtlichen und historischen Denkmale im Landkreis Friedland, ed. K. Uhlíková, Praha 2013 (Fontes historiae artium, vol. 15); V. Luksch, Topographie der historischen und kunst-Denkmale im politischen Bezirke Leitmeritz, Teil 1, Stadt Leitmeritz / Soupis historických a uměleckých památek v politickém okresu Litoměřice, Díl 1, Město Litoměřice, ed. K. Uhlíková, J. Chadimová, M. Barus, Praha 2015 (Fontes historiae artium, vol. 16); F. Mareš, J. Sedláček, Soupis památek historických a uměleckých v politickém okresu českokrumlovském, Svazek 2, Český Krumlov, ed. J. Marešová, Praha 2016 (Fontes historiae artium, t. 17; in the press).

20 Österreichische Kunsttopographie, published from 1907 onwards, 59 volumes so far.

${ }^{21}$ A large part of the original frottage is found in the estate of the Archaeological Commission of the CASA (see note 19) and in the planning collection of the Documentation Department of IAH of the CAS, v.v.i.
} 
This information concerns statistically-linguistic questions, questions of the inscriptions formulas and methods of dating, functional relations between the object and the local context, etc. ${ }^{22}$.

If we now turn to the prerequisites for Czech epigraphic work, we have to turn our attention to questions of personnel, and to the institutional and methodological bases for research. The last two decades have seen the gradual establishment of regular semester-length epigraphic lecture series at several Czech universities - such attention cannot be taken for granted in other European countries ${ }^{23}$. Previously, epigraphy was taught only marginally in the field of history, and never independently ${ }^{24}$. The problem remains of the transferral of acquired knowledge and interests to the next generations of researchers, because only a few job positions provide an opportunity for such narrowly conceived scientific work. So far, there is no specialised position in Bohemia in the field of post-antique Latin epigraphy - not to mention any specialised institutions. Even the minute centre Epigraphic and Sepulchral Studies at the Institute of Art History of the CAS, v.v.i, established in $2005^{25}$, only assures the epigraphic activities of its employees outside the framework of their basic daily responsibilities.

Closely related to university instruction is the methodological basis of Czech epigraphic research. It is oriented mainly on the methodology of German and Austrian epigraphy ${ }^{26}$, and hence emphasises the interdisciplinary nature of the approach to inscription monuments. This manifests itself in attention devoted not only to the inscriptions themselves, but also to the objects bearing them, and the historical and cultural-historical context in which they were made. In the interpretation of external and internal marks, the greatest emphasis is placed on the palaeographic analysis, which in practice contributes in a decisive fashion to the overall testimonial value of the inscription.

Czech literature does not have an epigraphic handbook in the strict sense of the word. The most extensive information for the students of history, specialists, and the educated lay public remains the chapter by Ivan Hlaváček in Vademecum pomocných véd historických [Vademecum of the Auxiliary Sciences of History] ${ }^{27}$, which provides only a brief orientation. Epigrafika v památkové péči [Epigraphy in Monument Care] is substantially longer ${ }^{28}$. It is conceived mainly as a practical guide for heritage preservation, for which it has been certified as representing the fundamental methodology ${ }^{29}$. The emphasis is placed on cataloguing and describing inscriptions, and on basic factual information on the external and internal marks of the inscriptions which ought to allow even a non-specialist at least a basic contextual interpretation. No attention is paid to important areas not directly related to

\footnotetext{
${ }^{22} \mathrm{Cf}$. e.g. the summary concerning the penetration of vernacular langauges into the Czech inscription heritage in F.A. Bornschlegel, J. Roháček, Innovation, Tradition, Korrelation. Die Inschriften Böhmens und des deutschen Reiches, in: Böhmen und das Deutsche Reich: Ideen- und Kulturtransfer im Vergleich (13.-16. Jahrhundert), ed. E. Schlotheuber, München 2009; and J. Roháček, Národní jazyky v teritoriálně českých náhrobních nápisech, in: Epigraphica et Sepulcralia, vol. 3, ed. idem, Praha 2011, pp. 405-418. Of the earlier works I mention the summary of basic infomation on the Czech historical campanological fund, J. Hejnic, Nápisy na Českých zvonech (see note 17); cf. also J. Roháček, Od jedinečnosti k reprezentativnosti (Malá úvaha nad epigrafickými pracemi Josefa Hejnice), in: Humanismus v rozmanitosti pohledü. Farrago festiva Iosepho Hejnic nonagenario oblata, ed. A. Bađurová, K. Boldan, A. Jelínková, M. Vaculínová, Praha 2014, pp. 69-76. ${ }^{23}$ Especially by the author of this paper, the longest running (since 1998) at the Department of History of the Faculty of Arts of J. E. Purkyně University; further at the Department of Auxiliary Historical Sciences and Archive Studies of the Faculty of Arts of the University of South Bohemia; and at least in two-year intervals also at the Department of Auxiliary Historical Sciences and Archive Studies of the Faculty of Arts of Charles University. The issue is divided here in four main areas: 1. Disciplinary context, basic terms; 2. External and internal marks of the inscriptions with an emphasis on inscription palaeography; 3. The inscription and its bearer; 4. Editorial and cataloguing practice. For the doctoral, magisterial and baccalaureate theses developed on the basis of these courses, cf. the information systems of the individual schools, esp. $<\mathrm{http}: / /$ knihovna.ujep.cz/> [accessed on: 9.03.2016].

${ }^{24}$ More in J. Roháček, Epigraphica bohemica docta, Acta universitatis carolinae (in the press).

$25<$ http://www.udu.cas.cz/cs/epigrafika $>$ [accessed on: 8.03.2016].

26 See note 7.

${ }^{27}$ I. Hlaváček, Epigrafika, in: Vademecum pomocných věd historických, 3rd amended and supplemented edition, Jinočany 2002, pp. 373-396, and further editions.

28 J. Roháček, Epigrafika v památkové péči, Praha 2007.

${ }^{29}$ Certificate of the Ministry of Culture of the CR No. 4/2013 OPP
} 
the focus of the publication, e.g. the history and context of the discipline. Nevertheless the book is used with success as a university textbook as well. We should not forget earlier works either, in particular the pioneering treatise by Václav Vojtíšek, who was the first to call for far greater attention, devoted to the preservation and study of the Czech inscriptions. Having dealt with the preservation of Czech inscriptions and their learned literature, one ought at least cursorily to summarise some historical information $^{30}$. As is typical for Czech epigraphy, this also is inspired directly by the German models of the period ${ }^{31}$. On editorial methodology, the treatise by Miroslav Flodr is still important ${ }^{32}$.

Which opportunities present themselves for the future development of Czech epigraphy? The accessibility of the Czech inscriptions remains a painful question, with problems starting already with their basic registry and not only of the inscriptions themselves but also that of the objects bearing them, the artistic and other material monuments ${ }^{33}$. Continuing the Corpus inscriptionum Bohemiae is certainly a priority task, but the systematic renewal of the work and its completion is a long-term issue. A sensible provisional measure and a preparation for fieldwork, is providing an electronic database of the inscriptions studied in the existing secondary literature and the sources, enabling accessibility of the inscriptions in the literature of other disciplines. Another matter is the questionnaire leading to an inventory of the secondarily preserved sepulchral and inscription monuments in the archives of the $\mathrm{CR}^{34}$, the digitisation of the already mentioned card catalogues of the epigraphic commission of the $\mathrm{CASA}^{35}$ and the preparation of a list of funds of graffiti.

We still have to wait for the publication of the epigraphic 'capstone of the pyramid', i.e. for a work which will provide a synthesising, or, if one prefers, a purposeful analytical view of our 'national' epigraphic heritage, based on a representative choice of the Czech epigraphic material and on a wider comparison with related European materials.

We may consider university instruction as in principle sufficient, but the problem of the available personnel and institutional embedding of 'real' epigraphy remains. This is related to the existentially important social 'demand', which we need to approach actively - in our own interest. First of all, we need cooperation with 'stronger' disciplines, particularly with art history ${ }^{36}$. The connection of epigraphic research with research on sepulchral monuments ${ }^{37}$, which are the main objects bearing inscriptions, may be especially productive. This consideration has been one of the reasons for the idea of annual international sessions on sepulchral (and in practice also epigraphic) monuments ${ }^{38}$, organized

\footnotetext{
${ }^{30}$ V. Vojtíšek, O potřebě soupisu a fotografování nápisů, „Zprávy památkové péče”, 4, 1940, pp. 20-23, 34-40 (reprinted without the pictorial supplements in: idem, Výbor rozprav a studií, Praha 1953, pp. 518-531). On the epigraphic work of Václav Vojtíšek, see I. Hlaváček, Václav Vojtíšek a epigrafika, „Studie o rukopisech”, 22, 1983, pp. 57-62.

${ }^{31}$ K. Brandi, Grundlegung einer deutschen Inschriftenkunde, „Deutsches Archiv”, 1, 1937, pp. 11-43 (reprinted in idem, Ausgewählte Aufsätze, Berlin 1938, pp. 64-89).

${ }^{32}$ M. Flodr, Zásady popisu středověkých a novověkých epigrafických památek, „Sborník prací Filozofické fakulty brněnské univerzity", 23-24, 1974-1975, pp. 167-174.

33 The central list of cultural monuments of the Czech Republic, kept by the National Heritage Institute, cannot be listed here as a suitable registry.

${ }^{34}$ J. Roháček, Projekt soupisu sekundárního dochování epigrafických a sepulkrálních památek ve fondech a sbírkách archivu České republiky, in: Epigraphica et Sepulcralia, vol. 3, ed. idem, Praha 2011, pp. 557-559.

${ }^{35}$ See Notes 4 and 5.

${ }^{36}$ For the latest on the topic, see J. Roháček, Možnosti, limity a úskali epigrafické výpovědi, in: Artem ad vitam. Kniha k poctě Ivo Hlobila, ed. H. Dáňová, K. Mezihoráková, D. Prix, Praha 2012; cf. also the presentation of stylistic parallels in: J. Roháček, Zum Verhältnis von epigraphischem und kunsthistorischem Stil in der frühen und späteren Neuzeit. Einige illustrierende Beispiele aus böhmischem und mährischem Material, in: Epigraphik 2000, ed. G. Mras, R. Kohn, Wien 2006 (Forschungen zur Geschichte des Mittelalters, vol. 10), pp. 107-118.

${ }^{37}$ Cf. the last 'declarative' work, J. Chlíbec, J. Roháček, Figure and Lettering. Sepulchral Sculpture of the Jagiellonian Period in Bohemia, Praha 2014. The inscriptions mentioned in their works usually take into consideration, at least on a descriptive basis, the views of art historians and historians; we would like to mention, apart from Miloslav Pojsl, and Petra Hrubý, a number of others, whose bibliography would exceed the allotted length of this paper (see also note 1).

${ }_{38}$ The latest to date, the fourteenth session, took place on 29-30 October 2015; the fifteenth session is planned for 1921 October 2016.
} 
by the author of this article from 2000 onwards, and the related publication series Epigraphica et Sepulcralia $^{39}$. Another imperative is applied research, which is not only the domain of the natural and technical disciplines. In the case of epigraphy, this includes a wide range of outputs, starting with various methodologies for public administration, heritage and restoration work ${ }^{40}$, and finishing with the research's implementation in exhibition projects. Popularisation activities are closely connected to this. They can take the form of popular scientific publications, providing access to inscriptions in various ways, contributions in mass media of all types, public lectures, etc. This will contribute to the formation of the cultural-historical awareness of the society, and may lead to desirable feedback that is not only beneficial for the study of inscribed monuments.

\section{Dlaczego istniejesz? \\ O dziejach, stanie obecnym i perspektywach czeskiej epigrafiki}

Streszczenie: Republika Czeska nie stoi na czele europejskich badań na polu średniowiecznej i nowożytnej epigrafiki. Mimo to jest w stanie zaprezentować interesujące i wartościowe rezultaty, zwłaszcza jeśli wziąć pod uwagę ograniczone zasoby czeskiej epigrafii. Udostępnianie czeskich inskrypcji ma długą tradycję, poczynając od licznych średniowiecznych działań, poprzez okres wczesnonowożytny i nowożytny. Jakie możliwości na przyszłość rysują się dla rozwoju czeskiej epigrafiki? Możemy rozważyć rozwiązanie uniwersyteckie jako w zasadzie wystarczające, ale wciąż pozostaje problem dostępnej kadry i osadzenia instytucjonalnego. Zwłaszcza katalogowanie i szersze syntezowanie stanowią naglący problem. Wiąże się to z życiowo ważnym społecznym ,żądaniem", do którego epigrafika musi podejść czynnie. Zwłaszcza współpraca z historykami sztuki i powiązanie badań epigraficznych z badaniami nad pomnikami nagrobnymi mogą okazać się tu szczególnie produktywne.

Author: D r J i r í R o há č e k, Czech Republic, born in 1962. Studied archive studies and the auxiliary sciences of history at the Faulty of Arts of Charles University in Prague. Head of the Department of Documentation and the Centre for Epigraphic and Sepulchral Studies at the Institute of Art History of the Academy of Sciences of the Czech Republic. His interests, publications, and teaching (at Charles University, the University of South Bohemia, and the J.E. Purkyně University) focus in particular on epigraphics, written sources for the history of art, and sepulchral monuments. Publisher of the Epigraphica et Sepulcralia series and member of a team issuing Artefactum and Convivium.

Jest wydawcą serii Epigraphica et Sepulcralia, a także członkiem zespołu wydającego Artefactum and Convivium. Nota o autorze: D r J i ř í R o há č e k, Republika Czeska, ur. 1962. Studiował archiwistykę i nauki pomocnicze historii na Wydziale Sztuk Uniwersytetu Karola w Pradze. Kieruje Zakładem Dokumentacji i Centrum Badań Epigraficznych i Sepulkralnych Instytutu Historii Szuki Akademii Nauk Republiki Czeskiej. Jego zainteresowania, publikacje i działalność pedagogiczna (na Uniwersytecie Karola, Uniwersytecie Południowoczeskim i Uniwersytecie J.E. Purkyně) koncentrują się zwłaszcza na epigrafii, źródłach pisanych do historii sztuki oraz na problematyce pomników nagrobnych.

Jest wydawcą serii Epigraphica et Sepulcralia, a także członkiem zespołu wydającego Artefactum and Convivium. e-mail: rohacek@udu.cas.cz

\section{Bibliography}

Epigraphica et Sepulcralia, ed. J. Roháček, 6 vols., 2005-, subserie Epigraphica et Sepulcralia - monographica, 3 vols., 2011-

Hlaváček I., Die mittelalterliche Epigraphik in den böhmischen Ländern nach dem zweiten Weltkrieg, „Medievalia Bohemica”, 3, 1970, pp. 293-311

Hlaváček I., Epigrafika, in: Vademecum pomocných věd historických, 3rd amended and supplemented edition, Jinočany 2002, pp. 373-396, and further editions

\footnotetext{
${ }^{39}$ Epigraphica et Sepulcralia (ed. J. Roháček), six volumes so far since 2005; in the subseries Epigraphica et Sepulcralia monographica, three volumes were published so far.

40 J. Roháček, Epigrafika (see note 28).
} 
Literaturbericht zur mittelalterlichen und neuzeitlichen Epigraphik (MGH, Hilfsmittel), 1987-

Načeradská P., Nápisy okresu Kutná Hora, Praha 2002

Roháček J., Středověká a raně novověká epigrafika v České republice, Corpus Inscriptionum Slovaciae, vol. 1.1, Súpis nápisov zo Slovenska, vol. 1.1, Latinská epigrafia. Dejiny a metodika výskumu historickych nápisov zo Slovenska, Bratislava 2014, pp. 31-40

Roháček J., Epigrafika v památkové péči, Praha 2007

Roháček J., Od jedinečnosti k reprezentativnosti (Malá úvaha nad epigrafickými pracemi Josefa Hejnice), in: Humanismus v rozmanitosti pohledi̊. Farrago festiva Iosepho Hejnic nonagenario oblata, ed. A. Bad'urová, K. Boldan, A. Jelínková, M. Vaculínová, Praha 2014, pp. 69-76

Roháček J., Nápisy města Kutné Hory, Praha 1996 (Corpus inscriptionum Bohemiae, vol. 1, Fontes historiae artium, vol. 3)

Soupis památek historických a uměleckých v království českém (v Čechách, v Republice československé) od pravěku do počátku XIX. Století, 51 sv., 1897-1937+ 5 vols. recently issued from the estate of the Archeaological Commission of the CASA

Vojtíšek V., O potřebě soupisu a fotografování nápisů, „Zprávy památkové péče”, 4, 1940, pp. 20-23 and 3440, reprinted without the pictorial supplements in: idem, Výbor rozprav a studiú, Praha 1953, pp. 518-531 